\title{
Effective moderation in asynchronous discussion forums in online language classrooms
}

\section{Eficacia de la moderación de foros de debate asíncronos en aulas de idiomas en línea}

Jackie Robbins

Universitat Autònoma de Barcelona

\begin{abstract}
This study investigates the effectiveness of different online language teaching practices by comparing participation of four groups of learners and teachers in two tasks in asynchronous discussion forums. The tasks are carried out in the context of an online English as a Foreign Language (EFL) B2 course at a Catalan university. Teacher posts to the forums are analysed qualitatively with the aim of identifying different types of teacher posts; we then run inferential statistics to compare student participation data in classrooms with different course completion rates and in two types of task. Findings indicate that when teachers participate in forum discussions as peers and ask questions that generate discussion, they are more likely to encourage learners to participate, a pattern that seems to emerge more clearly in classrooms with higher course completion rates.
\end{abstract}

Keywords: Online language learning; Discussion forums; Participation; Task type; Completion rate

\section{Resumen}

Este estudio investiga la eficacia de prácticas diferentes en la enseñanza de idiomas en línea, comparando la participación de cuatro grupos de estudiantes y profesores en dos tareas asíncronas en foros, en el contexto de un curso de inglés como lengua extranjera B2 en una universidad catalana. Los mensajes del profesorado se analizan de manera cualitativa; se realizan luego análisis estadísticos inferenciales para comparar los datos de participación de los estudiantes en aulas virtuales con índices de finalización diferentes y en dos tipos de tarea. Los resultados indican que, cuando los profesores participan en los debates como si fueran un miembro más y hacen preguntas para fomentar el intercambio, aumenta la probabilidad de participación de los estudiantes, un patrón que sobresale en aulas con mayores índices de finalización de curso.

Palabras clave: Aprendizaje de Idiomas en Línea; Foros de debate; Participación; Tarea; Índice de finalización 


\section{INTRODUCTION}

Online language teaching employs a range of online tools for specific communicative purposes. The present study focuses on one of these, namely the asynchronous discussion forum, which in the educational context studied in this article plays a central role throughout the course. Besides serving as the main locus where assessed written tasks take place, it is used by teachers for classroom management and technology issues and, questions about course content, but also learners engage in crucial social interaction with their peers and teacher here. Earlier research on forums focused on their use within online courses for content subjects (e.g. Garrison, Anderson, \& Archer, 1999; 2001; Meyer, 2003; Zhu, 2006), where the learners' linguistic competence is not a core competence. However, this study explores discussions amongst learners of a second language and their teachers, in which communication in the second language is an essential pedagogical aim of the course. The rationale for choosing the forum space and analysing its discussion patterns is to help unveil effective online teaching practices in forum spaces used for language learning.

This study picks up from earlier research by the author (Canals \& Robbins, 2017) aimed at identifying successful classroom practices in forum spaces through quantitative analyses of classrooms discussion forums. It does so by identifying variables that could account for course completion rates. The findings of the previous study linked the amount of students'- but not teachers'- posts to course completion rates. It was concluded that we needed to examine the contents of teachers' posts to see if there were differences in two different types of classrooms and two different types of task.

In the present study, we analyse the forum posts for two tasks from four classrooms with different degrees of completion rates; two classrooms with higher than average course completion rates (higher than .77) and two with lower than average course completion rates (.77 or lower). In terms of tasks, these differ in several dimensions: required and assessed or not, word length, topic, genre and overall aims. We take discussion threads as the unit of analysis, measuring how many threads students take part in, with the aim of understanding the amount and frequency of learner participation taking place. We anticipated finding differences in participation levels between the different classroom types and the different task types and hoped to relate these to different teacher actions in these classrooms and tasks. The following research questions guided this study: 
1. How does learner participation differ in discussion forums for tasks which are assessed and not assessed?

2. How are learner participation patterns different in classrooms with different completion rates?

3. What types of posts do teachers most commonly send to discussion forums for tasks which are assessed and not assessed?

4. How do teachers' posts differ in classrooms with different completion rates?

By addressing these questions, we hope to deepen our understanding of the relationship between teacher actions and learner participation in assessed and unassessed tasks, and the extent to which these affect course completion rates.

\section{THEORETICAL CONSIDERATIONS}

Contact with and opportunities to practise language in real-life communication events are central to language learning theories and pedagogical approaches in most language learning settings, but especially in online contexts, which offer limitless contact with authentic language and countless communication tools to suit different learning styles (AbuSeileek, 2009; Gurzynski-Weiss \& Baralt 2014; 2015; Dehkordi \& Hashemian, 2017). One communication tool employed in online language learning contexts is the moderated asynchronous discussion forum and understanding the dynamics of this learning environment and the role the teacher plays there may maximise the learner's educational experience. We draw from previous research in online education, online task-based language learning and the effect of task type on participation.

\section{The teachers' role in distance learning}

Particularly influential in the field of distance learning (DL) research is Garrison et al.'s (1999) work on the Community of Inquiry (CoI) model. This model considers that in addition to social presence, teaching presence is an essential aspect required for critical learning to take place in computer-mediated communication (CMC) in educational contexts. Many other studies have established the role the instructor plays in determining success of online courses (Volery \& Lord, 2000; McPherson \& Baptista Nunes, 2006; Selim, 2007; Menchaca \& Bekele, 2008; Puri, 2012; McGill, Klobas \& Renzi, 2014; van Rooij \& Zirkle, 2016). In this sense, Rovai (2007) notes the need for a focus on the new roles of online teachers within the context of social learning theory, in which learning "involves personal experiences, observations, and interactions with other individuals" (p. 77). For Rovai, facilitating a sense of community in asynchronous online discussions is crucial because, as 
he argues, these better support content and task-oriented discussions about real topics. Dixson (2010) agrees and points to the need for multiple student-student and instructor-student communication channels for students to maximise active learning. More recently, Boling, Hough, Krinsky, Saleem and Stevens (2012) recognise that the acquisition of higher psychological processes is rooted in interaction and, citing Kong and Pearson (2002), claim that learning happens while individuals interact with more knowledgeable members of a community (teacher or peers).

\section{Language learning and teaching in asynchronous discussion forums}

Hymes' (1971) theory of communicative competence and subsequent work by Canale and Swain (1980) prompted the development of Communicative Language Teaching, whereby real-life communicative practice and the acquisition of communicative competence is essential for language learning success. One of the dominant pedagogical approaches in language teaching this view has generated is Task-based Language Teaching (TBLT). A TBLT approach enables learners to work on reallife interactive tasks effectively, aided by the teacher.

Asynchronous discussion forums provide an optimum environment for TBLT as they offer learners time to process what they read before formulating their own contributions (Kitade, 2006). Forums also offer a supportive learning environment for language learners because they can foster the development of metacognitive and cognitive linguistic capacities among learners, create an environment appropriate for instructors to provide feedback, and encourage learners to develop a sense of community, which, in turn, promotes active learning (Brooke, 2013).

In this context, teachers need to be experts in how much and how often to step in, but also in how best to facilitate language learning through actions such as: moderation, prompting, reformulation, direct correction, clarification and providing recasts. There is little work focusing on how this translates to asynchronous computer-mediated communication for language learning. We aim to address this in the present study.

\section{Task types and student participation}

Different tasks affect the language produced in various ways. As Khamis (2009) claims, "the choice of appropriate task types can influence the quantity and quality of learner output" (p. 4).

Research into the effect of different task types on language output draws on Pica, Kanagy and Falodun's (1993) five task-type classification: information gap, 
jigsaw, problem-solving, decision-making, and opinion exchange. These task types vary in the degree of information exchange required, from information gap tasks that need the highest level of information exchange, to opinion exchange tasks which require the lowest. Opinion exchange tasks are open-ended, while information tasks are controlled. Smith (2003) compares participation between jigsaw and decision-making tasks in synchronous computer-mediated communication (SCMC), finding a significantly higher amount of negotiated turns in decision-making tasks. On the other hand, Kitade (2006) finds that jigsaw tasks promote negotiation in asynchronous CMC. Brandl (2012) investigates the effect of two tasks which differ in one aspect: whether the information exchange is optional or essential for completing the task. Brandl hypothesises that tasks in which information exchange is essential will generate more learner output than when information exchange is optional but finds instead that open-ended tasks lead to more production in terms of quantity of target language words and communication units.

Another factor identified as influencing student participation in online forums is whether tasks are assessed or voluntary. For example, Alzahrani (2017) finds assessment to be a critical factor which positively affects student participation in online forums in a range of subjects in Saudi Arabia. In a similar vein, but in the context of language learning, Rodríguez-Juárez and Oxbrow (2010) find evaluation to be a major factor affecting overall student participation in forums, although they suggest this is less a result of passivity and instead, more related to limited learner autonomy. They propose that increased teacher participation in tasks as a group member might increase student motivation and consequently lead to higher levels of participation by learners.

\section{Course completion and student participation}

For many online educational programmes, students can take a break between courses and return to study later so whether they should be included in retention figures or not is debatable (Grau-Valldosera, \& Minguillón, 2014). However, in relatively short individual courses, course completion rates can be an effective measure of success. If students persist and complete assignments and the course, they are more likely to learn or acquire the target competences than if they opt out. Several studies (Canals \& Robbins, 2017; Nistor \& Neubauer, 2010; Robbins, Malicka, Canals, \& Appel, 2015) have pointed to student participation as one of the main indicators affecting course completion in online language courses. Participation is also one of the crucial internal factors in Rovai's (2007) theoretical model of student attrition and, given its observable nature, Nistor and Neubauer (2010) 
see it as an accurate indicator of learners' intentions to persist in an online course. This article contributes to providing additional empirical evidence exploring participation patterns and their interconnection with course completion rates.

\section{Measuring participation in discussion forums}

Different researchers have proposed various approaches for measuring activity in discussion forums. Bliss and Lawrence (2009) provide an overview of these approaches, which either adopt multi-factor metrics or focus on specific factors such as participation, role of the teacher, quantity or quality of student posts. They point out that measuring discussion forums is complicated by the additional factors that can affect what happens in a discussion forum, in particular learner characteristics and course design. Within the context of online language learning for this study, we consider the following metrics for measuring participation in our forums.

\section{Quantity of student posts}

In a TBLT approach, learners are challenged to carry out a real-world activity that can help them learn and use the target language for meaningful communication. Tasks need to engage the learner "providing a communicative space for establishing a shared interpersonal focus (i.e., between the learner/communicator and one or more interlocutors or audiences)" (Bygate, Norris, \& Van den Branden, 2015, p. 2). One sign that students are engaged in a forum writing activity would be active participation, signalled by students posting at least the minimum required by the task. In the context of this study, where students are required to post a main contribution and responses to at least two classmates, we can calculate whether a particular forum shows signs of learner engagement or not by counting the total number of posts and establishing the average number of posts per student. Bliss and Lawrence (2009) propose that instead of basing this calculation on the number of students enrolled in the course as other researchers have done (Jiang \& Ting, 2000; Mazzolini \& Maddison, 2003; Picciano, 2002), posting rate should only take into account the number of participating students.

Modelling learner behaviour in discussion forums has been the subject of various studies seeking to establish the proportion of learners in a class that are highly engaged. In this sense, learners are categorised according to whether they read and write, read and occasionally write, or barely read or write posts to the forum at all. Most work focuses on the second category, often labelled as 'lurkers' as they often read but do not post (Mason, 1994; Taylor, 2002). In our context, our courses can only be passed by following the online course (i.e. taking part in 
the tasks in the forum are all minimum requirements to pass the course overall), so while lurkers exist, they would almost certainly not complete (and therefore fail) the course. For the purposes of this paper, we therefore focus on active participants.

\section{Quantity of teacher posts}

Given that the forums under scrutiny in the present paper constitute an essential communication space in the classroom, the quantity of teachers' posts could indicate to a certain extent the teacher's presence in the classroom. McPherson and Baptista Nunes (2004) describe the essential roles of teachers within the context of social learning theory, tying in with Garrison et al.'s (1999) idea of the positive impact teachers' teaching and social presence have on learners' own involvement in classroom discussions.

On the other hand, other studies conducted from a social constructive perspective indicate that excessive involvement on the part of the teacher can lead to lower engagement by learners. Earlier research conducted by the author of this paper (Canals \& Robbins, 2017) indicated that number of teachers' posts did not necessarily indicate higher completion rates in a given classroom. It was rather the amount of learners' posts which showed a positive correlation with completion rates. This is in line with Garrison and Cleveland-Innes (2005), who point out that it is "not educationally desirable or reasonable from a time-management perspective to have the teacher respond to each comment" (p. 145). In the context of this paper, we saw the need to analyse the content of teachers' posts in addition to quantifying them. Our account of the amount of teacher posts is merely a descriptive measure which needs to be nuanced by including information on the content of teacher posts.

\section{Types of teacher posts}

As outlined above, Garrison et al.'s (1999) work on the Community of Inquiry (CoI) model has been extremely influential in the field of CMC. Basing their work on the CoI, Shea and Bidjerano (2010) build on previous research by Garrison, Cleveland-Innes and Fung (2010) and claim that "the multivariate measure of learning represented by the cognitive presence factor could be predicted by the quality of teaching presence" (p. 1722). Similarly, Bliss and Lawrence (2009) argue that the type of teacher forum posts, rather than the quantity, is likely to help answer the question of what leads to more dialogue among learners.

Our context differs in two main aspects from the context of Garrison et al. (2010) and therefore we use the CoI framework as a theoretical starting point only. 
Firstly, our learners are communicating with the aim of practising a second language and for this reason, the teacher responses will necessarily be of a different nature to those of learners in a content-based subject; and secondly, our teachers are not directly involved in course design as this aspect is carried out by a subject coordinator. Following Gonzalez-Lloret's (2011) bottom-up, inductive, data driven approach to data analysis, for the purposes of this paper, we devise our own categories from the teacher posts themselves.

As we can surmise from the literature relating to methodological considerations for analysing participation in discussion forums, for the context of this study, the quantity of student posts can be a good indicator of learner engagement in forum discussions. While the number of teacher posts seems to be less helpful for encouraging student participation, considering the content of teachers' posts should provide us with a deeper appreciation of the role she plays.

\section{METHOD}

In the following section, we describe the study context and participants. We then provide details about how our data were selected and a description of the tasks. We conclude by describing how our data were analysed.

\section{Context and participants}

The context for the present study is a fully online B2.1 (upper-intermediate) English as a Foreign Language (EFL) course for adult learners. This 3-month course takes place over one semester at the Universitat Oberta de Catalunya (UOC) in Spain. Students are randomly assigned to a virtual classroom of approximately $50 \mathrm{stu}-$ dents with one teacher. The course adopts a TBLT approach and consists of input through self-correcting web-based materials and production tasks for the different skills. This study focuses on the individual writing tasks which are carried out in each classroom's asynchronous discussion forum. The teacher's role in the forums consists of setting up the different tasks, moderating, providing individual and whole-class language feedback in response to areas of confusion, and assessing students' work.

For the present study, we began by collecting quantitative data to use as a basis for identifying appropriate classrooms for subsequent qualitative analysis. First we established the completion rate for each classroom. In a previous study, we established the average course completion rate to be .77 (Canals \& Robbins, 2017) and therefore classrooms with higher than .77 completion rate were 
classified as 'above average' and those with lower than .77 completion rate were classified as 'below average'. This enabled us to select four classrooms for our analysis: S1 and S2 (both with above average course completion rates), and A1 and A2 (both with below average course completion rates). Table 1 shows the characteristics of the 4 classrooms. Teachers assigned to these classrooms had at least two years (four semesters) teaching experience in our institution.

Table 1. Classroom characteristics

\begin{tabular}{|c|c|c|c|c|c|c|}
\hline Classroom & Teacher & $\begin{array}{l}\text { Class } \\
\text { size }\end{array}$ & $\begin{array}{l}\text { Total \#teacher } \\
\text { posts }\end{array}$ & $\begin{array}{l}\text { Total \#student } \\
\text { posts }\end{array}$ & $\begin{array}{c}\text { Student } \\
\text { participation rate }\end{array}$ & $\begin{array}{c}\text { Course } \\
\text { completion rate }\end{array}$ \\
\hline S1 & T1 & 38 & 98 & 786 & 20.68 & 0.89 \\
\hline A1 & $\mathrm{T} 1$ & 34 & 98 & 607 & 17.85 & 0.74 \\
\hline S2 & T2 & 58 & 135 & 1349 & 23.26 & 0.81 \\
\hline A2 & T3 & 58 & 118 & 1027 & 17.71 & 0.74 \\
\hline
\end{tabular}

Table 1 shows that the classrooms ranged in size with two smaller ones ( $\mathrm{S} 1$ and A1) and two larger ones (S2 and A2). We can also observe the number of teachers' and students' posts in each classroom, which in some classrooms is well below the average of 112 for teacher posts and 942 for students' posts (classrooms S1 and A1) and some above average in all accounts (S2 and A2).

\section{Discussion forum tasks}

Discussion forum data comes from two tasks which were conducted following similar guidelines and instructions across the four classrooms under scrutiny. These two tasks differed in several aspects. The first task was a course warm-up task which was used to encourage learners to get to know one another and to familiarise them with the virtual learning environment. This task invites students to write 4060 words about themselves and read their classmates' contributions to identify people they have something in common with. This warm-up task is neither compulsory nor assessed but it does require participants to exchange information about themselves, making it essential at the start of a course as it involves learners sharing personal details and identifying common aspects with others, thereby encouraging a sense of group cohesion, which will be helpful as the course progresses.

The second task was an assessed task in which students were instructed to write 150-200 words, choosing from various essay questions, answering one of them and then reading and replying to at least two of their classmates (see Appendix). Students were not awarded marks for higher participation per se. This is 
a standard opinion exchange type of task which does not call for specific information exchange. It does however require students to display awareness of essaywriting conventions as well as level-specific linguistic features. The principal differences between the two tasks were in terms of whether the task was (a) required or assessed, (b) word length, (c) topic, (d) genre and (e) overall aims.

\section{Data analysis}

In order to address research questions 1 and 2, forum participation data were analysed using SPSS, and descriptive and inferential statistics were run through ANOVA tests in order to provide information about the means and standard deviations of teachers' and students' posts. In this way, we were able to compare their behaviour in different tasks and classrooms with different course completion rates.

\section{Teacher posts}

In order to address research questions 3 and 4, we analysed teachers' posts in the four classroom forums and categorised these. To do this, we filtered out all posts from the teachers and then two researchers separately classified them into types of posts, according to their principal communicative function. We then compared our coding, resolved any disagreements and established six categories of teacher posts.

In order to validate our categories we surveyed 46 teachers working on the same course, asking them to first confirm our six categories were comprehensive enough in terms of how they were defined but also if there were any other types of posts teachers felt were missing. Secondly, we asked teachers to order the six categories in terms of their likelihood to encourage learner participation in the discussion forum. Incorporating the feedback from this survey, we confirmed six types of teacher posts from less likely (type 0 ) to more likely (type 5 ) to generate participation among learners. In this way, we established the connection between the types of teacher posts and their likelihood for encouraging student participation.

\section{RESULTS}

The results we report are taken from discussion forums of the four different classrooms detailed in Table 1: two classrooms which were rated as higher than average in terms of students completing the course and two which were below average showed average amount of students completing the course. In each of the four classrooms we compare data between two different tasks: a warm-up conducted at 
the beginning of the course (during week one of a 13-week course) and an assessed task conducted later in the course (during week three). For research questions 1 and 2, which focus on the learners, we compare their participation in the two tasks and then the two different types of classrooms. In order to address research questions 3 and 4, which focus on the teacher, we analyse the type and amount of teacher posts in terms of the tasks and then in terms of course completion rates.

\section{Learner participation in different tasks in the two types of classrooms}

As we have seen in Table 1, class sizes ranged from 34 to 58 students. We calculated the average number of posts by students in each classroom as a way of showing the basic rate of participation in each classroom. Classrooms A1 and A2 were more similar according to this measurement than S1 and S2, despite having quite different classroom sizes (38 vs. 58 students). S1 and S2 had above average course completion rates (.89 and .81 respectively), whereas A1 and A2 had below average course completion rates $(.74)$.

Comparing posts in the warm-up and assessed tasks, in Table 2, we observe that during the warm-up, overall there was less participation (106 posts vs $141, M=123.5(S D=37.5)$, at a rate of 2.86 vs $3.71, M=3.29(S D=.64)$, posts per student, but the rate of participation by each student per thread was comparatively higher (1.23 posts per student vs 1.07 posts per student), $M=1.15$ ( $S D=.10)$.

Table 2. Differences between tasks: posts and participation of students per task

\begin{tabular}{c|cc|cc|cc}
\hline & \multicolumn{2}{|c|}{ Number of posts } & \multicolumn{2}{c|}{$\begin{array}{c}\text { Number of participat- } \\
\text { ing students in the task }\end{array}$} & \multicolumn{2}{c}{$\begin{array}{c}\text { Average post } \\
\text { per student }\end{array}$} \\
\hline Warm-up & $\begin{array}{c}\text { Assessed } \\
\text { task }\end{array}$ & Warm-up & $\begin{array}{c}\text { Assessed } \\
\text { task }\end{array}$ & Warm-up & $\begin{array}{c}\text { Assessed } \\
\text { task }\end{array}$ \\
\hline S1 & 85 & 146 & 28 & 36 & 3.03 & 4.06 \\
A1 & 67 & 95 & 27 & 27 & 2.48 & 3.52 \\
S2 & 137 & 179 & 44 & 41 & 3.11 & 4.37 \\
A2 & 134 & 145 & 47 & 50 & 2.85 & 2.90 \\
Average & 106 & 141 & 37 & 39 & 2.86 & 3.71 \\
Mean & 123.5 & & 37.5 & & 3.29 & \\
Sd & 37.5 & & 9.3 & & 0.64 & \\
\hline
\end{tabular}

We checked whether our data was normally distributed and found that regarding skewness and Kurtosis our data were somewhat skewed and kurtotic for both groups (warm up and assessed task) according to the Kolmogorov-Smirnov $(\mathrm{K}-\mathrm{S})$ test $(p>.05)$, but they did not differ significantly from normality. The Shapiro-Wilk test $(\mathrm{K}-\mathrm{S})$ test $(p>.05)$ was non-significant in all cases allowing us to 
keep the null hypothesis indicating that our data were approximately normally distributed. We proceeded to run parametric tests, a one-way ANOVA in order to determine the differences between the raw numbers of posts in different tasks (warm-up and assessed tasks). We observed significant differences in the average posts per student $[(1,7) F=5.76, p=.05]$ and this measure seems to be a good indicator of differences in participation when taking into consideration the element of assessment.

Essentially, classrooms with above average course completion rates do better in all accounts in terms of student participation in the discussion and this corresponds with a higher rate of teacher posts which contribute to fostering discussion.

\section{Types of teacher posts}

Table 3 shows the six categories of teacher posts that we identified in the four classrooms. We ranked these in order of their likelihood to foster participation after confirming this order by means of a short survey among all of our teachers. We considered that type- 0 posts, setting up activity and clarifying task instructions, while they clearly instruct learners to take part, do not do so any more than the published task guidelines in the classroom. Types 0 to 3 all require the teacher to write as teachers, whereas types 4 and 5 are posts which are peer-like in nature.

Table 3. Types of teacher posts

\begin{tabular}{|c|c|c|}
\hline $\begin{array}{l}\text { Post } \\
\text { type }\end{array}$ & Description & Example \\
\hline 0 & $\begin{array}{l}\text { Set up activity and task } \\
\text { instructions and/or } \\
\text { clarification of } \\
\text { instructions/answer } \\
\text { technical issue }\end{array}$ & $\begin{array}{l}\text { Setting up activity: } \\
\text { Hi Everyone, } \\
\text { Welcome to the classroom forum :) } \\
\text { In this area I will expect to see your written contributions to the } \\
\text { course as well as recordings for later activities. } \\
\text { If you have any questions or doubts just let me know, } \\
\text { I am looking forward to reading your first } \\
\text { contributions here in our Warm-up Activity! } \\
\text { Best wishes, } \\
\text { Clarification: } \\
\text { Dear Judith* and all, } \\
\text { The question mark at the end of the first sentence has } \\
\text { been typed by mistake, so it should not be there. It is not a } \\
\text { question. }\end{array}$ \\
\hline
\end{tabular}




\begin{tabular}{|c|c|c|}
\hline $\begin{array}{l}\text { Post } \\
\text { type }\end{array}$ & Description & Example \\
\hline 1 & $\begin{array}{l}\text { Thank for participation/ } \\
\text { encourage more } \\
\text { participation }\end{array}$ & $\begin{array}{l}\text { Dear students, } \\
\text { I can see that most of you have introduced yourselves in this warm } \\
\text { up activity, well done!!! } \\
\text { If you have not introduced yourself or you have } \\
\text { not replied to some of your classmates, you still have time to } \\
\text { do it!!! } \\
\text { So do not postpone it any more!!! } \\
\text { With very best wishes, }\end{array}$ \\
\hline 2 & Mini-quizzes & $\begin{array}{l}\text { Some of you wrote these sentences: } \\
\text { Can you correct them and tell me why they are wrong? } \\
\text {-I am completely agree with you. } \\
\text {-Actually people think that online universities... }\end{array}$ \\
\hline 3 & $\begin{array}{l}\text { Corrective feedback - } \\
\text { with links, grammar info, } \\
\text { etc. }\end{array}$ & $\begin{array}{l}\text { Dear students, } \\
\text { Here are the corrections: } \\
\text { - I completely agree with you. The verb "agree" does not } \\
\text { go with the verb "to be" in English } \\
\text {-Nowadays / currently people think that online universities... } \\
\text { As you said "actually" means "en realitat". }\end{array}$ \\
\hline 4 & $\begin{array}{l}\text { Participating in } \\
\text { the task as a participant }\end{array}$ & $\begin{array}{l}\text { Hi Mary and everyone else! } \\
\text { I agree with you; learning languages online or } \\
\text { in traditional institutions is different, each have their pros and cons, } \\
\text { in online classrooms we do miss the spontaneity, the free } \\
\text { conversation and the change of topic. On the other hand you do } \\
\text { have the flexibility and the structure to } \\
\text { help you achieve your learning aims and develop your language } \\
\text { skills in conjunction with others. } \\
\text { Good luck with your learning! } \\
\text { Best wishes, }\end{array}$ \\
\hline 5 & $\begin{array}{l}\text { Participating and asking } \\
\text { for more details }\end{array}$ & $\begin{array}{l}\text { Hi Anne and everyone else! } \\
\text { Welcome to the course Anne, I see you are a food lover, me too :) } \\
\text { Do you cook? I really enjoy cooking when I have the time! } \\
\text { Best wishes, }\end{array}$ \\
\hline
\end{tabular}

\section{Teachers' posts in different tasks}

Figure 1 shows the proportion of the different types of teachers' posts for the two tasks.

As can be observed in Figure 1, during the warm-up activity teachers mostly send posts thanking students for participating and encouraging them to participate more (33\% of their posts correspond to type- 1 posts as seen in the figure) at the beginning and then they mostly participate in the activity
Figure 1. Proportion of teachers' posts according to type in the two tasks

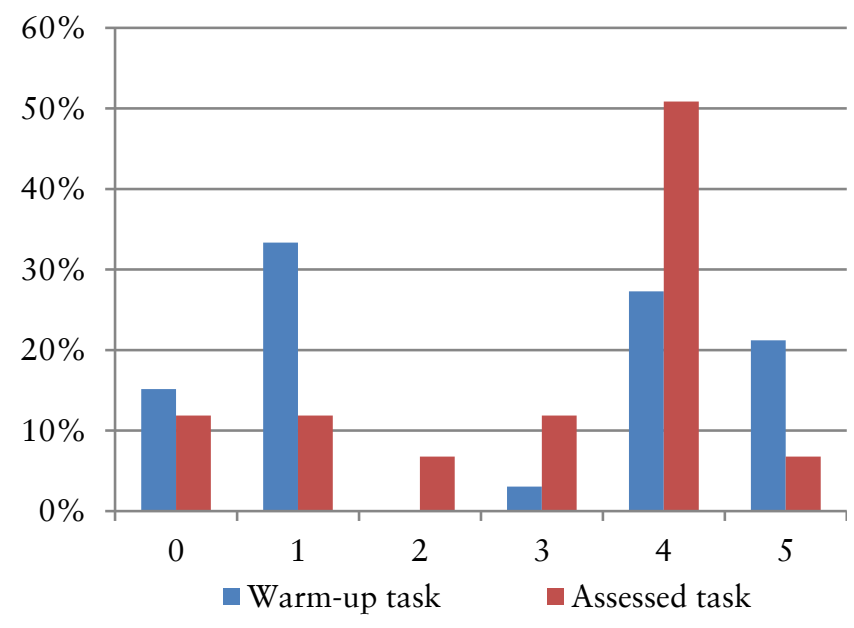


commenting on students posts as another participant and asking for more details. These later types of posts (27\% of type- 4 and $21 \%$ of type- 5 ) seem to be the ones more conducive to enhance participation.

During the assessed activity, we observe how the teachers set up the activity (post type- 0 constitutes $12 \%$ of the total number of posts), let the students take off with the task and then contribute mostly with type- 4 posts $(51 \%$ of all teachers' posts) where they participate in the activity commenting on students posts as if they were another participant. On fewer occasions teachers contribute by thanking students for their participation and encouraging more participation (type-1 posts), and they rarely offer mini-quizzes (type-2 posts), corrective feedback (type-3 posts) or participate in the discussion asking for more details (type-5 posts).

In conclusion, the warm-up activity seems to set the tone/mood, pace and pattern of participation in the forum which may then be contributing to more or less participation in classroom discussions later on in the course, as shown in the following section.

\section{Teacher posts in different types of classrooms}

Figure 2. Proportion of teacher post types in classrooms with above/below average course completion rates

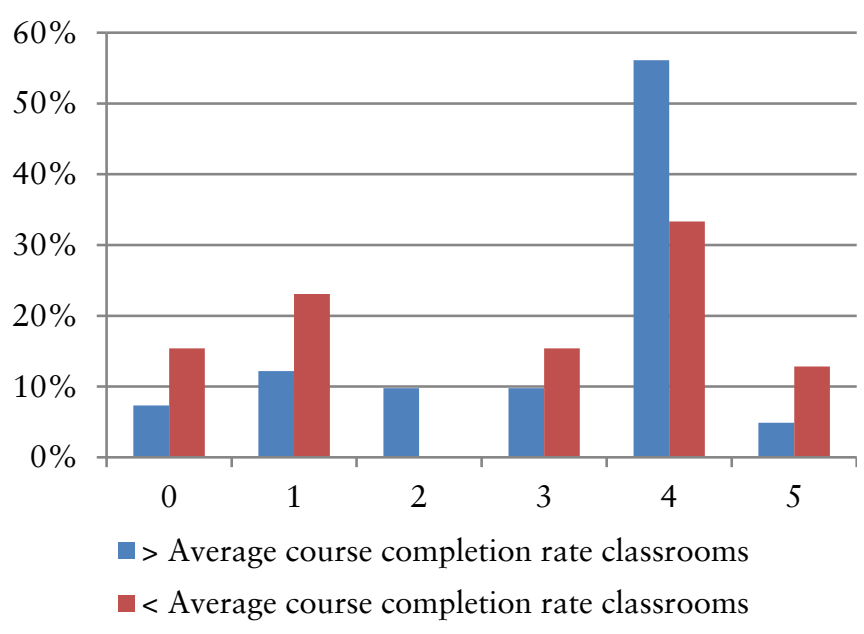

Figure 2 shows the proportion of teachers' posts according to type in the two types of classrooms.

Regarding the type of teacher posts, we notice that the pattern of teacher posts in classrooms with above average course completion rates resembles the one seen in the assessed activity. Namely, the teachers set up the activity but we observe mostly type4 posts $(56 \%)$ where teachers participate in the activity commenting on students' posts as if they were

another participant and on fewer occasions teachers clarifying instructions or answering technical questions ( $7 \%$ of type- 0 posts), thanking students for their participation and encouraging more participation (12\% of type- 1 posts) and participating in the discussion asking for more details ( $5 \%$ type-5 posts). However, average classrooms teacher posts are more evenly distributed among all post types, 
type- 1 posts averaging $23 \%$ of the total posts while type- 4 posts reaching about $33 \%$ of the total teachers posts.

Classrooms with higher than average course completion rates do noticeably better in reproducing the pattern shown in the assessed activity (mostly type-4 posts where the instructor takes part in the activity) than classrooms with lower than average rates, where we observe a higher variety of teachers posts: teachers clarifying instructions or answering technical questions (type-0 posts), thanking students for their participation and encouraging more participation (type- 1 posts), providing corrective feedback (type-3 posts) or participating in the discussion asking for more details (type-5 posts).

Essentially, classrooms with above average course completion rates do better in all accounts in terms of student participation in the discussion and this corresponds with a higher rate of teacher posts which contribute to fostering discussion.

\section{DISCUSSION}

This study sought to investigate the effectiveness of teacher actions on learner participation in asynchronous discussion forums in different tasks and with different completion rates. In earlier studies (Robbins, et al. 2015; Canals \& Robbins, 2017) the number of posts per instructor did not show a significant correlation with more student posts. In the present study, however, it seems that different types of teachers' posts may contribute to encouraging learner participation. This seems to be especially true for posts where teachers participate in the activity commenting on students' posts as if they were part of the group, which is consistent with earlier studies, such as Bliss and Lawrence (2009), who found that teachers who showed presence without dominating the discussion were still able to facilitate in an effective way. The fact that the teacher is modelling social behaviour in the community was also brought up by Boling et al. (2012) who highlighted the importance of the teacher's role in providing a model of effective participation in an online context.

When comparing learner participation between different tasks, we have observed significant differences between the warm-up and the assessed task in terms of overall amount of participation (average posts per student). The way teachers in these classrooms participate in their forums, that is by participating in the discussions as another member of the group, seems to have a positive effect on learner participation, as shown in the results when we compared student participation in 
different tasks and the corresponding higher rates of specific types of teacher posts in those same tasks.

We did find evidence that participation patterns in the forum vary considerably between those with above average completion rates and classrooms with below average completion rates. As expected, the above average classrooms display higher participation; specifically, students posted more, but also, more students participated in the discussions, with a higher number of posts across tasks (assessed and warm up).

With regard to whether the actions that teachers perform in the discussion forum vary between different types of tasks, it is unsurprising that teachers focus their efforts on thanking learners and encouraging them to post more in a warm up task than in a subsequent assessed task as one of the aims of a warm up task is to build the group dynamic; however, it is curious to note the marked difference between the number of posts in which the teacher takes part in the task as another member of the group and not so much as a teacher in the assessed task compared with this type of post sent to the warm up. This seems to confirm Heiser, Stickler and Furnborough's (2013) claim that an effective teacher should be able to create optimum social contexts and teach learners how to use these. We have seen that in classrooms with above-average course completion rates, teachers continued the pattern of posting in a similar way to learners (responding to the content of what learners write) established in the warm-up into the subsequent assessed task. On the other hand, in the classrooms with below-average completion rate, teachers tended to vary the type of post and include more 'teacher-style' posts such as corrective feedback and encouraging students to participate more.

One of the aims of this paper was to consider how participation among learners in the discussion forum is related to teacher action there and also to determine whether the participation rates among learners established in the warm-up task in the forum is related to that of the assessed task that follows it. In light of the data analysed here, in which we have observed that when teachers take part in an earlier task as a participant, it does seem to have a beneficial effect on learner participation in a subsequent task, and we feel there is evidence to support both assumptions, although we would clearly need to analyse a much larger data set to confirm these claims. 


\section{CONCLUSIONS}

The wider motivation for our research lies in understanding and consequently facilitating the role the teacher plays in online language learning. What teachers (and learners) do in the forum seems crucial for task completion and it can affect the overall rhythm and tone of the class which will ultimately have an impact on course-completion rates. We have observed that by motivating and engaging learners, by participating in the discussions themselves as another member of the group, teachers can help increase participation levels as participation in itself tends to foster even more participation. In our context, this means increased levels of language practice which could have a positive impact on language learning, or at the very least enhance the likelihood for learning to occur.

In terms of limitations of our study, as we have indicated above, while the findings here seem to indicate that teachers who focus their forum posts more on taking part in activities rather than posting language feedback encourage learner participation, we will need to look at a much bigger sample to confirm this. The classrooms we selected may not be fully representative of all language classrooms in our educational setting.

The current study also provided important information about the type of posts which help moderate discussion forums and contribute to increasing student participation which can potentially be included in initial teacher training and continuous professional development, something which the author intends to examine in further researches. In the context of this study, where the primary objective of discussion forum tasks is to provide learners with a reason for maximising effortful and engaged communication, the primary role of the online language teacher is to 'read' the group and (evidenced by the use of type- 4 posts overall and more prominently in classrooms that show higher completion rates) step in, modelling 'good' learner behaviour and showing presence to encourage learners to continue interacting and therefore getting more communicative practice.

The fact that during the warm-up task, we observed teacher behaviour that we did not expect would foster learner participation as much as it did (that is, thanking learners and encouraging them to participate more), could be related to the fact that this task was the very first task in the course. This means we will need to revise our categorisation of teacher posts in future studies and we would also need to include analyses of optional, or non-required tasks taking place later in the course. 
The findings and conclusions of this study could potentially be extrapolated to online programmes other than language learning. Therefore, this paper also contributes to expand the growing body of research on online, blended and distance educational discussion forums.

\section{ACKNOWLEDGEMENT}

The author would like to thank her PhD supervisor, Laia Canals, for her invaluable help with carrying out the statistical analyses for this study and for providing feedback and help during the writing and revision stages.

\section{ETHICAL STATEMENT}

This research adheres to all data protection practices in the European Union and within the institution from which the data is taken.

\section{APPENDIX}

Task questions for assessed task:

- Why did you choose to study online and how does it differ from your previous learning experiences?

- How can you minimise the loneliness of studying online?

- Can you learn absolutely anything online?

The assessed task also requires students to reply to at least two of their classmates, including responses to the following questions:

- Do you share the writer's experiences and/or thoughts?

- Can you give the writer any advice about learning online?

- Did you learn anything from their essay (ideas or language items)?

\section{REFERENCES}

AbuSeileek, A. F. (2009). The effect of using an online-based course on the learning of grammar inductively and deductively. ReCALL, 21(03), 319-336. https://doi.org/10.1017/s095834400999005x

Alzahrani, M. G. (2017). The effect of using online discussion forums on students' learning. Turkish Online Journal of Educational Technology, 16(1), 164-176. http://www.tojet.net/

Bliss, C. A., \& Lawrence, B. (2009). From posts to patterns: A metric to characterize discussion board activity in online courses. Journal of Asynchronous Learning Networks, 13(2), 1532. https://doi.org/10.24059/olj.v13i2.1665 
Boling, E. C., Hough, M., Krinsky, H., Saleem, \& Stevens, M. (2012). Cutting the distance in distance education: Perspectives on what promotes positive, online learning experiences. Internet and Higher Education. 15, 118-126. https://doi.org/10.1016/j.iheduc.2011.11.006

Brandl, K. (2012). Effects of required and optional exchange tasks in online language learning environments. ReCALL, 24(1), 85-107. https://doi.org/10.1017/S0958344011000309

Brooke, M. (2013). Facilitating the development of the autonomous language learner using online virtual learning environments. Theory and Practice in Language Studies, 3(4), 572-580. https://doi.org/10.1007/11853862_5

Bygate, M., Norris, J., \& van den Branden, K. (2015). Task-based language teaching. In C. A. Chapelle (Ed.), The encyclopedia of applied linguistics.

https://doi.org/10.1002/9781405198431.wbeal1467

Canale, M., \& Swain, M. (1980). Theoretical bases of communicative approaches to second language teaching and testing. Applied linguistics, 1(1), 1-47. https://doi.org/10.1093/applin/1.1.1

Canals, L., \& Robbins, J. (2017). An exploratory study of feedback practices for written and oral tasks in an online English course. In K. Borthwick, L. Bradley \&

S. Thouësny (Eds.), CALL in a climate of change: adapting to turbulent global conditions - short papers from EUROCALL 2017, 62-66. https://doi.org/10.14705/rpnet.2017.eurocall2017.690

Dehkordi, M. H., \& Hashemian, M. (2017). The effect of social networks on Iranian L2 learners' metaphorical competence. Modern Journal of Language Teaching Methods, 7(1), 3037. https://mjltm.org/browse.php

Dixson, M. D. (2010). Creating effective student engagement in online courses: What do students find engaging? Journal of the Scholarship of Teaching and Learning, 10(2), 1-13. https://scholarworks.iu.edu/journals/index.php/josotl/article/view/1744

Garrison, D. R., Anderson, T., \& Archer, W. (1999). Critical inquiry in a text-based environment: Computer conferencing in higher education. The Internet and Higher Education, 2(2), 87-105. https://doi.org/10.1016/S1096-7516(00)00016-6

Garrison, D. R., Anderson, T., \& Archer, W. (2001). Critical thinking, cognitive presence, and computer conferencing in distance education. American Journal of Distance Education, 15(1), 7-23. https://doi.org/10.1080/08923640109527071

Garrison, D. R., \& Cleveland-Innes, M. (2005). Facilitating cognitive presence in online learning: Interaction is not enough. American Journal of Distance Education, 19(3), 133-148. https://doi.org/10.1207/s15389286ajde1903_2

Garrison, D. R., Cleveland-Innes, M., \& Fung, T. S. (2010). Exploring causal relationships among teaching, cognitive and social presence: Student perceptions of the community of inquiry framework. The internet and higher education, 13(1-2), 3136. https://doi.org/0.1016/j.iheduc.2009.10.002

González-Lloret, M. (2011). Conversation analysis of computer-mediated communication. CALICO Journal, 28(2), 308-325. https://doi.org/10.11139/cj.28.2.308-325

Grau-Valldosera, J., \& Minguillón, J. (2014). Rethinking dropout in online higher education: The case of the Universitat Oberta de Catalunya. The International Review of Research in Open and Distributed Learning, 15(1), 1-19. https://doi.org/10.19173/irrodl.v15i1.1628

Gurzynski-Weiss, L., \& Baralt, M. (2014). Exploring learner perception and use of task-based interactional feedback in FTF and CMC modes. Studies in Second Language Acquisition, 36(01), 1-37. https://doi.org/10.1017/S0272263113000363

Gurzynski-Weiss, L., \& Baralt, M. (2015). Does type of modified output correspond to learner noticing of feedback? A closer look in face-to-face and computer-mediated task-based 
interaction. Applied Psycholinguistics, 36(6), 1393-

1420. https://doi.org/10.1017/S0142716414000320

Heiser, S., Stickler, U., \& Furnborough, C. (2013). Student training in the use of an online synchronous conferencing tool. CALICO Journal, 30(2), 226-251. https://doi.org/10.11139/cj.30.2.226-251

Hymes, D. (1971). Competence and performance in linguistic theory. In R. Huxley \& E. Ingram (Eds.), Language acquisition: Models and methods (pp. 3-28). New York: Academic Press.

Jiang, M., \& Ting, E. (2000). A study of factors influencing students' perceived learning in a webbased course environment. International Journal of Educational Telecommunications, 6(4), 317-338. http://ijet.pl/index.php/ijet

Khamis, H. (2009). Decision-making tasks in computer-mediated communication (CMC). Teaching English with Technology, 9(1), 3-17. https://www.tewtjournal.org/

Kitade, K. (2006). The negotiation model in asynchronous computer-mediated communication (CMC): negotiation in task-based email exchanges. CALICO Journal, 23(2), 319-348. https://doi.org/10.1558/cj.v23i2.319-348

Kong, A., \& Pearson, P. D. (2002). The road to participation: The evolution of a literary community in the intermediate grade classroom of linguistically diverse learners (Report 3[017]). CIERA/University of Michigan.

Mason, R. (1994). Using communication media in open and flexible learning. London: RoutledgeFalmer.

Mazzolini, M., \& Maddison, S. (2003). Sage, guide or ghost? The effect of instructor intervention on student participation in online discussion forums. Computers \& Education, 40(3), 237-253. https://doi.org/10.1016/s0360-1315(02)00129-x

McGill, T. J., Klobas, J. E., \& Renzi, S. (2014). Critical success factors for the continuation of elearning initiatives. The Internet and Higher Education, 22, 2436. https://doi.org/10.1016/j.iheduc.2014.04.001

McPherson, M., \& Baptista Nunes, M. (2004). The role of tutors as an integral part of online learning support. European Journal of Open, Distance and E-Learning, 1. http://eprints.whiterose.ac.uk/999/

McPherson, M., \& Baptista Nunes, M. (2006). Organisational issues for e-learning: Critical success factors as identified by HE practitioners. International Journal of Educational Management, 20(7), 542-558. https://doi.org/10.1108/09513540610704645

Menchaca, M. P., \& Bekele, T. A. (2008). Learner and instructor identified success factors in distance education. Distance education, 29(3), 231-252. https://doi.org/10.1080/01587910802395771

Meyer, K. A. (2003). Face-to-face versus threaded discussions: The role of time and higher-order thinking. Journal of Asynchronous Learning Networks, 7(3), 55-65. https://doi.org/10.24059/olj.v7i3.1845

Nistor, N., \& Neubauer, K. (2010). From participation to dropout: Quantitative participation patterns in online university courses. Computers \& Education, 55(2), 663672. https://doi.org/10.1016/j.compedu.2010.02.026

Pica, T., Kanagy, R., \& Falodun, J. (1993). Choosing and using communication tasks for second language instruction. Clevedon, UK: Multilingual Matters.

Picciano, A. G. (2002). Beyond student perceptions: Issues of interaction, presence, and performance in an online course. Journal of Asynchronous learning networks, 6(1), 21-40. https://doi.org/10.24059/olj.v6i1.1870 
Puri, G. (2012). Critical success factors in e-learning-an empirical study. International Journal of Multidisciplinary Research, 2(1), 149-161. https://eprajournals.com/journals.php?jid=1

Robbins, J., Malicka, A., Canals, L., \& Appel, C. (2015). Online communication in a higher education EFL course: The role of student and teacher activity in student retention. In E. K. Sorensen, A. Szucs \& M. S. Khalid (Eds.). Proceedings of the 1st D4 Learning International Conference Innovations in Digital Learning for Inclusion (D4Learning, 2015) (pp. 152-159). Aalborg, Denmark: Aalborg University Press. https://doi.org/10.13052/jcsm2245-1439.421

Rodríguez Juárez, C., \& Oxbrow, G. (2010). Encouraging participation in online discussion forums with university EFL learners. Estudios de Lingüistica Inglesa Aplicada, 10, 137166. https://doi.org/10.13140/2.1.2743.5204

Rovai, A. P. (2007). Facilitating online discussions effectively. The Internet and Higher Education, 10(1), 77-88. https://doi.org/10.1016/j.iheduc.2006.10.001

Selim, H. M. (2007). Critical success factors for e-learning acceptance: Confirmatory factor models. Computers \& Education, 49(2), 396413. https://doi.org/10.1016/j.compedu.2005.09.004

Shea, P., \& Bidjerano, T. (2010). Learning presence: Towards a theory of self-efficacy, self-regulation, and the development of a communities of inquiry in online and blended learning environments. Computers \& Education, 55(4), 17211731. https://doi.org/10.1016/j.compedu.2010.07.017

Smith, B. (2003). Computer-mediated negotiated interaction: An expanded model. The Modern Language Journal, 87(1), 38-57. https://doi.org/10.1111/1540-4781.00177

Taylor, J. C. (2002, June 5-7). Teaching and learning online: The workers, the lurkers and the shirkers. Plenary conference presented at 2 nd Conference on Research in Distance \& Adult Learning in Asia: CRIDALA. Hong Kong.

van Rooij, S. W., \& Zirkle, K. (2016). Balancing pedagogy, student readiness and accessibility: A case study in collaborative online course development. The Internet and Higher Education, 28, 1-7. https://doi.org/10.1016/j.iheduc.2015.08.001

Volery, T., \& Lord, D. (2000). Critical success factors in online education. International journal of educational management, 14(5), 216-223. https://doi.org/10.1108/09513540010344731

Zhu, E. (2006). Interaction and cognitive engagement: An analysis of four asynchronous online discussions. Instructional Science, 34(6), 451-480. https://doi.org/10.1007/s11251-006-0004-0

\section{JACKIE ROBBINS}

Holds an MA in Applied Linguistics from the Open University (UK) and is currently working towards a $\mathrm{PhD}$ in Education at the $\mathrm{UAB}$, focusing on learner engagement in online language learning. Her other research interests include task design, and adaptation for language learners with special needs. 
Robbins, J. (2020). Effective moderation in asynchronous discussion forums in online language classrooms . Bellaterra Journal of Teaching \& Learning Language \& Literature, 13(4), e898. https://doi.org/10.5565/rev/jtl3.898

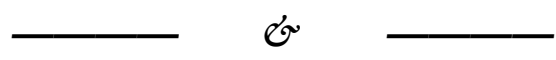

Rebut / Recibido / Received / Reçu: 04-05-2020

Acceptat / Aceptado / Accepted / Accepté: 07-10-2020 